\title{
Kontroversi Implementasi Kebijakan Penenggelaman Kapal Dalam Rangka Pemberantasan Illegal Fishing di Indonesia
}

\section{The Controversial Implementation of Ship Sinking Policy in the attempt of eradicating Illegal Fishing in Indonesia}

\author{
Chairun Nasirin ${ }^{1}$, Dedy Hermawan ${ }^{2}$ \\ ${ }^{1}$ Sekolah Tinggi Ilmu Kesehatan Mataram, \\ 2 Jurusan Administrasi Negara, FISIP, Universitas Lampung \\ Email: chairun_nasirin@yahoo.com
}

\begin{abstract}
Abstrak
Pencurian sumber daya ikan di laut Indonesia telah menimbulkan kerugian besar sektor perikanan dalam rangka mewujudkan kesejahteraan masyarakat. Kementerian Kelautan dan Perikanan mengambil kebijakan tegas untuk memberantas illegal fishing melalui tindakan penenggelaman kapal pelaku illegal fishing. Penelitian ini bertujuan untuk menganalisi dan membahas implementasi kebijakan penenggelaman kapal pelaku illegal fishing dan reaksi lingkungan yang timbul akibat kebijakan tersebut. Metode penelitian yang digunakan studi kepustakaan dan dokumentasi. Hasil penelitian ini memperlihatkan bahwa pelaksanaan kebijakan penenggelaman kapal oleh Kementerian Kelautan dan Perikanan merupakan model top down yang ditandai oleh kepastian peraturan, sistem komando yang kuat, pola instruksional dan koordinasi yang efektif, dukungan anggaran, dan dukungan birokrasi yang tangguh. Implementasi kebijakan ini juga telah menimbulkan reaksi lingkungan kebijakan yang keras berupa protes dari negara-negara tempat asal kapal-kapal yang ditenggelamkan. Secara empiris, hasil penelitian dapat membantu memperbaiki implementasi kebijakan pemberantasan illegal fishing dengan tindakan penenggelaman kapal, khususnya pada aspek pengelolaan reaksi lingkungan kebijakan agar dikemudian hari dapat lebih kondusif dan mendukung implementasi kebijakan.
\end{abstract}

Kata kunci: implementasi kebijakan, lingkungan kebijakan, penenggelaman kapal

\begin{abstract}
Illegal fishing in Indonesian sea has resulted in big loss in fishery sector in the attempt of realizing the people wellbeing. Maritime and Fishery Ministry makes firm policy to eradicate illegal fishing through sinking the ship of illegal fishing perpetrator. This research aimed to analyze and to discuss the implementation of policy of sinking the illegal fishing perpetrator's ship and environment's reaction to the policy. The research method employed was library study and documentation. The result of research revealed that the implementation of ship sinking policy by Maritime and Fishery Ministry is a top-down model characterized with regulation certainty, strong command system, effective instructional and coordination pattern, budget support, and strong bureaucratic support. This policy implementation has generated reaction within the environment to the tight policy in the form of protests made by the countries from which the ships sunk come. Empirically, the result of research could help
\end{abstract}


improve the implementation of illegal fishing eradication policy through ship sinking action, particularly in the aspect of managing the policy environment's reaction in order to be more conducive and supporting the implementation of policy later.

Keywords: Policy Implementation, Policy Environment, Ship Sinking

\section{Pendahuluan}

Indonesia merupakan negara maritim dan kepulauan terbesar di dunia. Sebagai negara maritim Indonesia memiliki luas wilayah perairan $6.315 .222 \mathrm{~km}^{2}$, panjang garis pantai $99.093 \mathrm{~km}^{2}$, dan jumlah pulau 13.466 pulau yang bernama dan berkoordinat. (www.bakosurtanal.go.id). Kemudian, menurut Konvensi Hukum Laut United Nations Convention on the Law of the Sea atau UNCLOS, Indonesia mempunyai hak eksklusif untuk memanfaatkan sumber daya kelautan seluas 2,7 $\mathrm{km}^{2}$ pada perairan Zona Ekonomi Eksklusif (ZEE) (Mahmudah, 2015).

Status sebagai negara maritim dibuktikan dengan fakta bahwa sekitar 70\% wilayah Indonesia adalah laut. Selama ini laut dengan kekayaan sumber daya di dalamnya telah berkontribusi besar terhadap pembangunan di Indonesia untuk mewujudkan kesejahteraan masyarakat. Kekayaan sumber daya laut Indonesia begitu melimpah, seperti rumput laut, terumbu karang, ikan, dan sebagainya. Ikan adalah salah satu kekayaan laut Indonesia yang sangat berharga dan menjadi penggerak roda perekonomian bangsa. Potensi kelautan dan perikanan di Indonesia dapat dilihat dari beberapa aspek seperti PDB sektor perikanan 1.239.591,80 milyar (2017), produksi perikanan tangkap 5.435.633 ton (2012), nilai ekspor hasil perikanan US\$1.000:2.092.302,01 (2016), dan produksi perikanan tangkap di laut menurut alat tangkap dengan rincian jaring lingkar 1.177.615, pukat tarik 690.629, pukat hela 324.880 , penggaruk 124.495, jaring angkat 494.561, jaring insang 1.394.473, perangkap 307.802, pancing 1.468.744, dan alat penjepit 54.455. (http://statistik.kkp.go.id).

Besarnya kekayaan laut dan perikanan Indonesia belum bisa dimanfaatkan secara optimal. Terhadap kondisi tersebut, Presiden Jokowi memberikan evaluasi sekaligus tantangan sebagai berikut: "70 persen dua per tiga luas wilayah Indonesia adalah lautan. Potensinya sangat besar untuk menjadi penggerak perekonomian nasional. Masalahnya, hingga saat ini potensi tersebut belum bisa dimanfaatkan secara maksimal oleh masyarakat". (http://www.dikti.go.id/). Salah satu kendala dalam optimalisasi kekayaan perikanan laut Indonesia adalah maraknya ilegal fishing di perairan laut Indonesia. Kerugian Indonesia akibat illegal, unreported, and unregulated fishing (IUU fishing), menurut Direktorat Jenderal (Ditjen) Pengawasan Sumber Daya Kelautan dan Perikanan (PSDKP) KKP diperkirakan Indonesia mengalami kerugian sebesar Rp. 101.040 triliun/tahun akibat IUU Fishing. (http://id.beritasatu.com).

KKP sebagai leading sektor utama dalam pengelolaan dan pemanfaatan kekayaan laut dan perikanan telah mengambil kebijakan tegas untuk memberantas illegal fisihing. Salah satu tindakan tegas tersebut 
adalah penenggelaman kapal asing dan eks-asing sebagai langkah nyata dalam implementasi UU No. 45 Tahun 2009 tentang Perikanan. Tindakan penenggelaman kapal merupakan aksi negara dalam memberantas kegiatan perikanan illegal dan di samping itu untuk memberikan efek jera serta meningkatkan efek detterence atau daya tangkal terhadap pelanggaran wilayah yang dapat merugikan dan mengancam kedaulatan negara. Berdasarkan data yang dirilis oleh Ditjen PSDKP KKP (2016) sampai bulan Februari 2016 telah 153 Kapal Ikan ditenggelamkan, untuk kapal asing meliputi 20 Kapal Ikan dari Malaysia, 43 dari Filipina, 1 dari RRT, 21 dari Thailand, 50 dari Vietnam, 2 dari Papua Nugini, 1 dari Belize, $1 \quad$ Nigeria. (http://djpsdkp.kkp.go.id)

Kebijakan penenggelaman kapal asing dan eks-kapal asing telah menimbulkan sejumlah kontroversi dan polemik. Pertama, dari aspek hukum tindakan tegas penenggelaman kapal dengan cara pengeboman tidaklah bertentangan dengan UNCLOS dikarenakan subyek yang dilindungi oleh Article 73 (3) adalah manusianya bukan kapalnya, dimana manusianya dapat diberi denda atau deportasi tanpa diberikan pidana kurungan sedangkan kapalnya dapat disita atau bahkan ditenggelamkan oleh Pemerintah Indonesia, tentu saja dengan proses yang sesuai dengan prosedur hukum yang berlaku di negara itu. Namun, dalam konteks hubungan internasional relasi Indonesia dengan negara yang bersangkutan berpotensi memburuk akibat permasalahan ini. Hal ini dikarenakan seringkali negara yang bersangutan ingin warganya diadili menurut hukum yang berlaku di negara mereka, hukum yang dianggap dapat melindungi hak-hak warga negaranya. Belum lagi tekanan kepentingan dari beberapa pihak dari negara tersebut (www. pssat.ugm.ac.id).

Kedua, perlu diingat juga bahwa perbuatan penembakan terhadap kapal milik negara lain juga menyalahi ketentuan Piagam PBB yang mengikat Indonesia sebagai anggota PBB. Sebagai "peace loving country", Indonesia harus menyelesaikan setiap konflik yang timbul secara damai. Karena itu, bentuk penembakan dan penenggelaman kapal milik asing jelas bukan merupakan cara menyelesaikan konflik dengan damai dan bukan merupakan ciri dari negara yang beradab (civilized nation). Aksi tersebut dapat mengakibatkan tegangnya hubungan politis seperti layaknya yang terjadi pada Filipina dengan Taiwan pada 2013 dan Republik Rakyat China (RRC) dengan Vietnam pada tahun yang sama. Apabila ketegangan politis terus berlanjut, bukan tidak mungkin potensi konflik bersenjata akan terjadi yang tentunya tidak diinginkan karena kita sedang giat melakukan pembangunan nasional dan APBN kita masih deficit (www.nasional.sindonews.com).

Ketiga, kebijakan penenggelaman kapal nelayan asing menggunakan bom memiliki dampak positif dan menjadi syok terapi agar nelayan asing tidak seenaknya mencuri ikan di perairan Indonesia. Namun, upaya tersebut tentu harus melalui proses hukum internasional agar Indonesia tidak dikatakan sebagai negara preman. Selain itu, alangkah baiknya kapal-kapal yang ditangkap dilelang, kemudian hasilnya masuk ke kas 
negara dalam bentuk Pendapatan Negara Bukan Pajak (PNBP) dan sekaligus sebagai alternatif hukuman yang tidak merusak lingkungan.

Pelelangan kapal bisa dilakukan setelah ada putusan resmi pengadilan yang membuktikan nelayan asing tersebut mencuri ikan di perairan laut Indonesia, sehingga merugikan negara (http://wartaekonomi.co.id). Suatu kebijakan publik idealnya dirancang dan dilaksanakan secara optimal dalam rangka memberikan manfaat sebesarnya bagi kepentingan masyarakat. Untuk itu, menurut Anderson (1976), setidaknya ada enam kriteria dalam memilih dan menetapkan suatu kebijakan publik, yaitu: (1) nilai-nilai yang dianut baik oleh organisasi, profesi, individu, kebijakan, maupun ideology; (2) afiliasi partai politik; (3) kepentingan konstituen; (4) opini masyarakat; (5) penghormatan terhadap pihak lain; dan (6) adalah aturan kebijakan itu sendiri. Selanjutnya, kebijakan publik yang baik adalah kebijakan yang berkualitas tinggi. Menurut Hallsworth, dkk (2000) (dalam Kementerian PPN/Bappenas, Australian Aid, Pusat Pembinaan Analis Kebijakan dan LAN, 2015) tingginya kualitas kebijakan ditandai oleh beberapa hal diantaranya, yaitu: pertama, memperhatikan dan mempertimbangkan lingkungan kebijakan atau dengan kata lain memperhatikan faktor-faktor eksternal dalam proses pembuatan kebijakan (outward looking). Kedua, terbuka terhadap ide dan solusi yang baru (inovatif, kreatif dan fleksibel). Ketiga, selalu memperhatikan dampak kebijakan terhadap semua pihak yang terkait baik secara langsung maupun tidak langsung (inclusive). Selain itu, karakter kebijakan publik yang baik harus juga memiliki karakter forward looking yang mengarah pada outcome dan mempertimbangkan dampak jangka panjang (The First Minister and Deputy First Minister, 2015 dalam Kementerian PPN/Bappenas, Australian Aid, Pusat Pembinaan Analis Kebijakan dan LAN, 2015). Memperhatikan berbagai pandangan ahli kebijakan diatas, maka dapat dinilai bahwa Kebijakan KKP menenggelamkan kapal asing dan ekskapal asing sebagai upaya pemberantasan illegal fishing belum sepenuhnya menjadi kebijakan publik yang ideal.

Berdasarkan uraian latar belakang diatas, penelitian ini ingin mengkaji bagaimana sebenarnya implementasi kebijakan penenggelaman kapal asing dan eks-asing yang telah dilakukan oleh Kementerian KKP dalam rangka pemberantasan illegal fishing. Kemudian bagaimana reaksi lingkungan kebijakan penenggelaman kapal asing dan eks-asing yang telah dilakukan oleh Kementerian KKP dalam rangka pemberantasan illegal fishing? Inilah secara garis besar yang akan dikaji dalam penelitian ini.

Esensi kebijakan publik sejatinya merupakan formula manjur di dalam menyelesaikan berbagai persoalan publik. Berbagai kajian telah dilakukan dalam rangka memberikan cara pandang dan pedoman untuk merancang kebijakan publik yang ideal dari sejak formulasi, implementasi, dan evaluasi. Ada beberapa pandangan para ahli kebijakan yang digunakan dalam penelitian ini sebagai perspektif untuk memahami dan menjelaskan fenomena kebijakan penenggelaman kapal asing dan eks-asing 
yang telah dilakukan oleh Kementerian KKP dalam rangka pemberantasan illegal fishing.

Anderson (2003) mengemukakan beberapa ciri dari kebijakan, yaitu sebagai berikut:

"Pertama, the definition links policy to purposive or goal-oriented action rather than to random behavior or chance occurrences. Kedua, policies consist of courses or patterns of action taken over time by governmental officials rather than their separate, discrete decisions. Ketiga, public policies emerge in response to policy demands, or those claims for action or inaction on some public issue made by other actors-private citizens, group representatives, or legislators and other public officials-upon government officials and agencies. Keempat, policy involves what governments actually do, not just what they intend to do or what officials say they are going to do. Kelima, policy involves what governments actually do, not just what they intend to do or what officials say they are going to do".

Menurut pendapat Anderson diatas, dapat dikemukakan lima ciri kebijakan publik, yaitu: pertama, kebijakan publik berorientasi tujuan, bukan asal-asalan. Kedua, kebijakan publik merupakan pola tindakan pemerintah yang berkelanjutan, bukan parsial. Ketiga, kebijakan publik merupakan respon atas isu-isu publik yang diartikuasikan oleh berbagai aktor masyarakat. Keempat, kebijakan publik benar-benar melingkupi tindakan nyata pemerintah, bukan sebatas keinginan dan niat untuk bertindak. Kelima, kebijakan publik sifatnya mengatur masyarakat yang dapat berbentuk pembolehan ataupun pelarangan.
Kebijakan publik bersifat dinamis yang ditentukan oleh berbagai aspek. Menurut Subarsono (2006), ada 6 aspek yang membentuk kerangka kebijakan publik. Pertama, tujuan yang akan dicapai. Aspek tujuan ini memiliki derajat kompleksitas yang berbeda-beda, semakin rumit tujuan yang ingini dicapai, maka effort kinerja kebijakan semakin tinggi. Demikian sebaliknya, semakin sederhana tujuan kebijakan, maka pelaksanaan kinerja kebijakan semakin ringan. Kedua, preferensi nilai yang menjadi pertimbangan pembuatan kebijakan. Apabila kebijakan dikonstruksi oleh berbagai preferensi nilai, maka pencapaian nilai kebijakan akan semakin sulit untuk dicapai, demikian pula sebaliknya. Ketiga, sumber daya yang mendukung pelaksanaan kebijakan publik seperti dana, material, dan infrasrtuktur lainnya. Keempat, kapasitas aktor yang terlibat dalam pembuatan kebijakan. Kapasitas aktor tersebut menjadi penentu baik buruknya kualitas suatu kebijakan. Kelima, dinamika lingkungan sosial, ekonomi, politik, dan lainya yang turut menjadi penentu kinerja kebijakan publik. Keenam, ketersediaan strategi yang akan digunakan untuk mencapai tujuan kebijakan. Strategi implementasi kebijakan sendiri meliputi strategi bersifat top down, bottom up, otoriter, dan demokratis.

Proses kebijakan publik berlangsung secara dinamis. Interaksi beragam aktor, kepentingan, lingkungan, dan sebagainya terjadi pada tahap formulasi, implementasi, hingga evaluasi kebijakan. Melalui pendekatan sistem dapat dijelaskan bagaimana suatu proses kebijakan publik berjalan dinamis sebagai akibat interaksi yang saling terkait, ketergantungan dan 
saling mempengaruhi antara kebijakan publik dengan lingkungan kebijakan. Kebijakan publik sebagai suatu sistem dijelaskan oleh Dunn (2004) sebagaimana terlihat pada gambar 1.

Gambar 1 memperlihatkan bahwa kebijakan publik merupakan hasil interaksi timbalik yang dinamis antara kebijakan publik dengan pelaku kebijakan, kebijakan publik dengan lingkungan kebijakan, dan pelaku kebijakan dengan lingkungan kebijakan. Walaupun institusi negara sebagai aktor utama dalam pembuatan kebijakan, namun dalam iklim demokrasi aktor kebijakan non pemerintah dapat memberikan kontribusi dalam pembuatan kebijakan.

Gambar 1. Hubungan Tiga Elemen Sistem Kebijakan

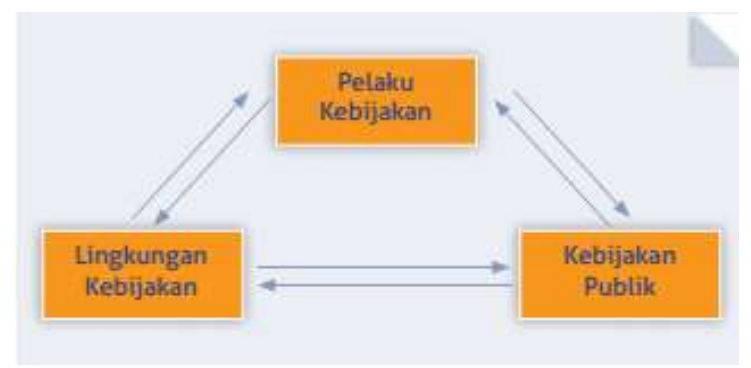

Sumber: Dunn, 2004.

Penelitian ini merupakan penelitian implementasi kebijakan publik. Implementasi kebijakan publik adalah tahapan berikutnya setelah tahap formulasi kebijakan publik. Berbeda dengan formulasi kebijakan publik, tahap implementasi kebijakan mengandung logika top down dengan mengoperasionalkan kebijakan abstrak menjadi tindakan nyata (Wibawa, dkk, 1994). Pendapat Van Meter dan Horn menyatakan bahwa implementasi kebijakan publik merupakan proses umum tindakan administratif yang dapat dikaji pada level program dan kegiatan (Wibawa, dkk., 1994). Sedangkan Anderson (1976) berpendapat bahwa implementasi kebijakan publik berkaitan dengan para pelaku yang mengoperasionalkan kebijakan, kegiatan-kegiatan para pelaku tersebut, dan dampak dari isi kebijakan. Kemudian, Howlet dan Rames (dalam Subarsono, 2006) mengemukakan pendapat implementasi kebijakan publik merupakan proses untuk melaksanakan kebijakan supaya mencapai hasil.

Implementasi kebijakan dapat dipahami melalui berbagai perspektif, seperti perspektif implementation problem, perspektif administrasi, perspektif politik, perspektif kepatuhan dan faktual, dan sebagainya. Pendekatan yang akan digunakan dalam kajian ini adalah pendekatan politik dalam memahami implementasi kebijakan. Pendekatan ini dipilih karena mencermati realitas dinamika implementasi kebijakan penenggelaman kapal untuk memberantas illegal fishing oleh Kementerian Kelautan dan Perikanan. Kebijakan tersebut sarat kepentingan dan melibatkan beragam stakeholder serta menimbulkan kontroversi dalam pelaksanaannya.

Perspektif administrasi menjadi tidak memadai untuk memahami dan menjelaskan fenomena kebijakan penenggelaman kapal oleh Kementerian Kelautan dan Perikanan. Perspektif politik dalam implementasi kebijakan publik merupakan reaksi dari kelemahan pendekatan administrasi yang hanya memandang bahwa implementasi kebijakan dalam rangka pencapaian 
efektivitas dan efisiensi. Perspektif politik melihat implementasi kebijakan lebih dari sekedar otoritas formal dan manajemen implementasi, implementasi sebagai suatu proses yang melibatkan tekanan berbagai kelompok kepentingan, para politisi di legislatif, dan faktor politis lainnya. (Mazmanian dan Sabatier, 1983).

Arena implementasi kebijakan ditandai penekanan pentingnya input, dinamika perubahan preferensi publik, perkembangan teknologi informasi, dan konsistensi output kebijakan dengan tujuan. Implementasi kebijakan publik secara umum memiliki berbagai model yang telah dirumuskan oleh para ahli kebijakan. Kebijakan yang langsung dilaksanakan dan dikendalikan oleh institusi pemerintah merupakan model implementasi top down, model kelembagaan, model administrasi dan model rasional (Sabatier, 1986 dan Grindle, 1980). Model top down meliputi didalamnya model elit, model proses, dan model inkremental. Sedangkan model top down terdiri atas model kelompok dan model kelembagaan (Sabatier, 1983). Kemudian ada model proses politik dan administrasi yang diperkenalkan oleh Grindle yang menggambarkan bahwa pengambilan keputusan sebagai proses politik yang melibatkan berbagai aktor kebijakan, sedangkan proses administrasi terlihat pada operasionalisasi program yang merupakan tindak lanjut dari keputusan politik (Grindle, 1980).

\section{Gambar 2. Model Implementasi Proses}

Politik dan Administrasi

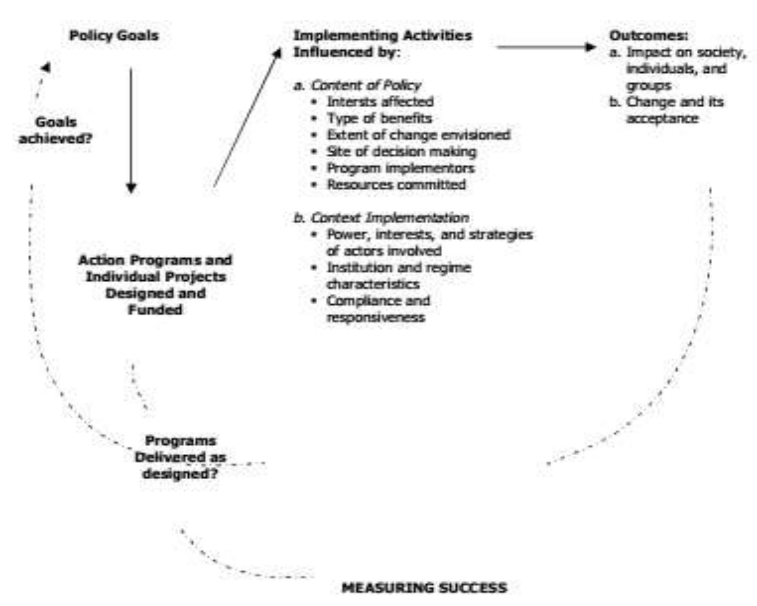

Sumber: Grindle (1980:11)

Model ini masuk kategori model top down, dimana pada tahap pelaksanaan kebijakan bersandar pada kejelasan tujuan, diformulasi melalui program dan proyek aksi, dan dirancang serta didukung sumber pembiayaan. Implementasi kebijakan dipengaruhi oleh isi dan konteks implementasi. Seluruh implementasi kebijakan dievaluasi dengan melihat perbandingan tujuan dengan capaian luaran dan dampaknya. Kata kunci dari model implementasi kebijakan model top down adalah komando, perubahan, kontrol dan kepatuhan.

Kinerja kebijakan ditentukan oleh beberapa variabel seperti isi kebijakan, organisasi pelaksana, dan lingkungan (Grindle, 1980 dan Quade, 1984). Variabel kebijakan untuk mengukur ketepatan pilihan kebijakan terhadap masalah publik yang akan diselesaikan. Pilihan kebijakan yang tepat dan dilaksanakan secara maksimal akan berimplikasi pada kepuasan masyarakat. Variabel organisasi pelaksana merupakan indikator operasionalisasi dari kebijakan yang telah dipilih melalui 
kewenangan, anggaran, sumber daya manusia, materi dan sebagainya untuk mengatasi masalah publik. Variabel lingkungan tidak bisa diabaikan untuk mendukung kinerja kebijakan. Lingkungan yang kondusif akan membantu pelaksanaan kebijakan dalam mengatasi masalah publik. Demikian juga sebaliknya, lingkungan yang tidak kondusif dan kontra akan menjadi hambatan pelaksanaan kebijakan bahkan sampai pada titik ekstrem lingkungan bisa menolak suatu kebijakan.

Keberhasilan implementasi kebijakan ditentukan oleh tiga aspek menurut Ripley dan Franklin (1986); pertama, tingkat kepatuhan birokrasi terhadap birokrasi atasnya sesusai dengan ketentuan perundang-undangan yang meligitimasi hirarkhi antar birokrai. Kedua, terwujudnya kegiatan rutinitas yang lancar dan tidak terganggu oleh masalah-masalah. Ketiga, keselarasan antara pelaksanaan kebijakan dan dampak yang diinginkan dari semua program dan kegiatan berada dalam arah yang benar sesuai rancangan kebijakan. Implementasi kebijakan publik yang sifatnya top down senantiasa ditentukan oleh faktor kekuatan dan paksaan dari pusat yang mendapatkan mandat jelas dari peraturan perundangundangan.

Penelitian ini menggunakan perspektif politik dan masalah, model top down, dan kriteria keberhasilan implementasi kebijakan yang ditentukan oleh faktor isi kebijakan, organisasi pelaksana, dan kondisi lingkungan. Semua hal tersebut digunakan untuk memahami, menganalisis, dan menjelaskan fenomena implementasi kebijakan penenggelaman kapal oleh
Kementerian Kelautan dan Perikanan dalam rangka memberantas illegal fishing.

\section{Metode Penelitian}

Penelitian ini menggunakan pendekatan studi kepustakaan dengan metode penelitian berbasis data sekunder. Menurut Nazir (2009), studi kepustakaan adalah teknik pengumpulan data dengan mengadakan studi penelaahan terhadap buku-buku, litertur-literatur, catatancatatan dan laporan-laporan yang ada hubungannya dengan masalah yang dipecahkan. Peranan studi kepustakaan sangat penting sebab dengan melakukan kegiatan ini hubungan antara masalah, penelitian-penelitian yang relevan dan teori akan menjadi lebih jelas. Selain itu penelitian akan lebih ditunjang, baik oleh teori-teori yang sudah ada maupun oleh bukti nyata, yaitu hasil-hasil penelitian, kesimpulan dan saran. Penelitian studi kepustakaan segala usaha yang dilakukan oleh peneliti untuk menghimpun informasi yang relevan dengan topik atau masalah yang akan atau sedang diteliti. Informasi itu dapat diperoleh dari buku-buku ilmiah, laporan penelitian, karangan-karangan ilmiah, tesis dan disertasi, peraturanperaturan, ketetapan-ketetapan, buku tahunan, ensiklopedia dan sumber-sumber tertulis baik tercetak maupun elektronik. 


\section{Pembahasan}

\section{A. Implementasi Kebijakan Penengge- laman Kapal Asing dan Eks Asing untuk Pemberantasan Illegal Fishing}

Kebijakan penenggelaman kapal asing dan eks asing yang dilakukan oleh Kementerian Kelautan dan Perikanan merupakan wujud dari visi kedaulatan negara dibidang kelautan dan perikanan. Kementerian Kelautan dan Perikanan telah menetapkan visi kedaulatan, yaitu "Membangun kedaulatan yang mampu menopang kemandirian ekonomi dalam pengelolaan sumber daya kelautan dan perikanan". Visi tersebut kemudian dioperasionalisasikan kedalam misi berupa kebijakan "Membangun kedaulatan yang mampu menopang kemandirian ekonomi dalam pengelolaan sumberdaya kelautan dan perikanan. Untuk mewujudkan misi tersebut disusunlah beberapa strategi yang salah satunya memberantas Ilegal, Unreported dan Unregulated (IUU) Fisihing. (http://kkp.go.id). Salah satu tindakan operasional pemberantasan IUUF yang dilakukan oleh KKP adalah penenggelaman kapal (Rencana Strategis Kementerian Kelautan dan Perikanan 2015-2019). Pelaksanaan kebijakan penenggelaman kapal asing dan eks-asing oleh KKP ditandai dengan beberapa fenomena kegiatan, yaitu:

Pertama, dukungan kepastian peraturan perundang-undangan, keputusan presiden, dan ketetapan lembaga penegak hukum yang meligitimasi pelaksanaan kebijakan penenggelaman kapal. Sejak KKP dipimpin oleh Susi Pudjiastuti, telah menenggelamkan hingga sebanyak 151 kapal penangkapan ikan secara ilegal di berbagai daerah di Tanah Air. Jumlah tersebut sebagian besar berasal dari sejumlah negara tetangga, antara lain 50 kapal Vietnam, 43 kapal Filipina, 21 kapal Thailand, 20 kapal Malaysia, dua kapal Papua Nugini, serta satu kapal Tiongkok dan 14 kapal berbendera Indonesia (https://m.tempo.co).

Sejumlah kapal asing dan eks-asing yang telah ditenggelamkan tersebut memiliki landasan hukum seperti instruksi presiden dan keputusan tetap dari pengadilan. Penenggelaman kapal berdasar instruksi presiden dapat dilihat pada kasus penenggelaman 16 kapal yang sudah ditangkap dan langsung ditenggelamkan tanpa melalui porses peradilan. Hal tersebut sebagaimana dinyatakan oleh Menteri KKP Susi Pudjiastuti berikut ini: "Kemarin saya sudah mendapat perintah dari Pak Presiden, sekarang kan proses penenggalaman kapal setelah inkrah, kita tidak akan lakukan itu lagi, jadi tidak memakan biaya, waktu, dan lainnya," (http://bisnis.liputan6.com).

Sebelumnya penenggelaman kapal didasarkan keputusan pengadilan, sebagai contoh dapat dilihat pada kasus peledakkan 40 kapal tanggal 20 Mei 2015 merupakan tindak lanjut dari putusan pengadilan yang telah memiliki kekuatan hukum tetap. (http://bisnis.liputan6.com). Semua tindakan penenggalaman kapal pelaku illegal fishing dilaksanakan mengacu pasal 69 UU No 45/2009 tentang perubahan atas UU 31 Tahun 2004 tentang perikanan yaitu dalam melaksanakan fungsi yang dimaksud ayat 1 penyidik dan/atau pengawas perikanan dapat melakukan tindakan khusus berupa pembakaran dan/atau penenggelaman 
kapal perikanan yang berbendera asing dengan bukti cukup. (http://bisnis.liputan6.com).

Kedua, melaksanakan pola instruksional dan koordinasi penenggelaman kapal asing dan eks asing pelaku illegal fishing. Kebijakan penenggelaman kapal dijalankan dengan pola instruksional dari Presiden kepada Kementerian KKP dan Lembaga Peradilan kepada Kementerian KKP.

Selain itu, implementasi kebijakan penenggelaman kapal juga berkoordinasi dengan instansi terkait lainnya seperti Kementerian Politik, Hukum dan Keamanan, Kementerian Luar Negeri, Kedutaan Besar Negara lain di Indonesia, TNI Angkatan Laut, dan sebagainya. Ada beberapa contoh kasus penenggelaman kapal yang menggambarkan adanya pola instruksional dan koordinasi

Ketiga, implementasi kebijakan penenggelaman kapal asing dan eks asing dilaksanakan dengan komitmen tinggi top manajemen, sehingga pelaksanaan kebijakan tersebut memiliki karakter progresif, konsisten, tegas, dan berkesinambungan. Komitmen para elit kebijakan yang membuat implementasi kebijakan penenggelaman kapal dapat berlangsung sejak tahun 2014, 2015, dan 2016. Komitmen yang kuat telah mendorong realisasi kebijakan secara nyataa dan akhirnya membuahkan hasil yang jelas. Walaupun kebijakan penenggelaman kapal tersebut mendapatkan kecaman dari dalam negeri maupun luar negeri, namun tindakan penenggelaman kapal tetap dilaksanakan.
Keempat, dukungan pendanaan untuk pemberantasan illegal fishing memudahkan pelaksanaan penenggelaman kapal. Pada tahun 2016, Satgas yang dipimpin langsung oleh Menteri Susi sebagai Komandan Satgas ini mendapatkan alokasi anggaran sebesar Rp 1 triliun dalam RAPBN 2016 untuk berburu pencuri ikan di lautan Indonesia. Anggaran tersebut terbagi untuk 2 periode operasi yang lamanya 6 bulan per periode, masingmasing periode operasi mendapat alokasi anggaran $\quad \mathrm{Rp} \quad 500 \quad$ miliar. (https://finance.detik.com).

Gambar 3 memperlihatkan dukungan dana $15,14 \%$ untuk program prioritas Pengawasan Sumberdaya Kelautan dan Perikanan dari total APBN 2016 untuk KKP. Perhatian untuk Pengawasan Sumberdaya Kelautan dan Perikanan mendapatkan perhatian cukup besar dengan posisi ketiga terbesar alokasi anggaran untuk KKP setelah alokasi program perikanan tangkan sebesar 28,70\% dan Sistem Rantai Dingin dan Logistik sebesar 15,28\%. Bahkan dukungan dana implementasi kebijakan penenggelaman kapal berlanjut tahun 2017. "Dalam rangka melaksanakan pemberantasan illegal fishing dan kegiatan yang merusak sumber daya kelautan dan perikanan, Ditjen PSDKP pada tahun 2017 menyiapkan anggaran senilai Rp 855,37 miliar tahun ini," kata Direktur Penanganan Pelanggaran Direktorat Jenderal Pengawasan Sumber Daya Kelautan dan Perikanan (PSDKP) KKP Fuad Himawan (https://kumparan.com). 
Gambar 3. Profil APBN KKP Program

Prioritas 2016

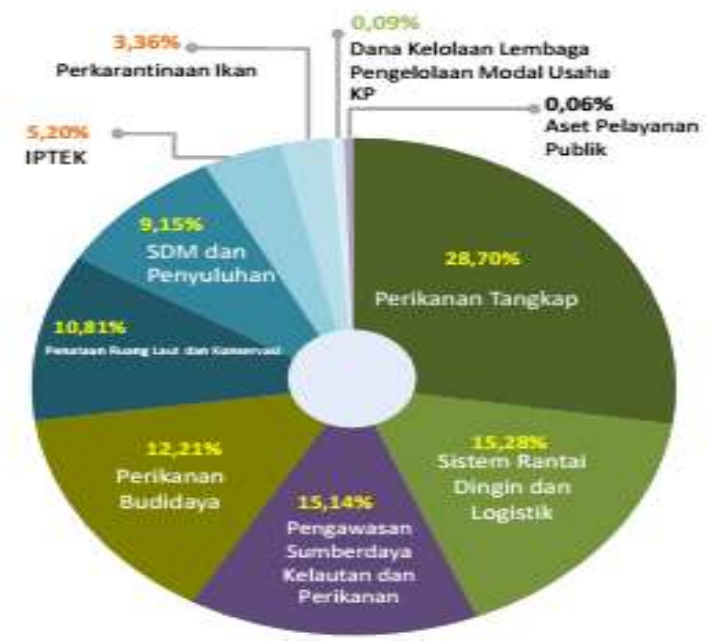

Sumber: http://kkp.go.id/wpcontent/uploads/2016/04/1.-SEKJEN.pdf.

Kelima, dukungan instrumen birokrasi Satuan Tugas 115 atau dikenal dengan Satgas 115 yang handal untuk mengeksekusi penenggelaman kapal. Satuan Tugas (Satgas) 115 ditugaskan untuk melakukan Pemberantasan Penangkapan Ikan Secara Ilegal melalui Peraturan Presiden No. 115 Tahun 2015 tentang Satuan Tugas Pemberantasan Penangkapan Ikan Secara Ilegal. Sejak diresmikan, satgas telah menghasilkan kinerja yang baik dan mendapatkan apresiasi Presiden RI. Berikut ini beberapa prestasi Satgas 115 sejak ditetapkan oleh Priseden RI pada 19 Oktober 2015; 1) Ada 176 kapal pelaku illegal fishing yang telah ditenggelamkan, 2) Bersama Ditjen Pajak Kementerian Keuangan mengembalikan kerugian negara akibat penangkapan ikan secara ilegal diperkirakan terdapat potensi pajak sebesar Rp 209,1 miliar dari 187 Wajib Pajak/pemilik kapal ikan eks-asing, 3) Hingga bulan Juni 2016, Satgas 115 telah menangani 11 kasus tindak pidanan perikanan, 4) Telah bekerjasama dengan
International Organization for Migration (IOM) memulangkan korban ke negara masing-masing dan membantu para korban mendapatkan pembayaran gaji yang semula tidak dibayarkan oleh perusahaan $\begin{array}{lll}\text { sebesar } & \text { USD } & 900.000\end{array}$ (http://news.kkp.go.id).

Berdasarkan pemaparan data diatas, implementasi kebijakan penenggelaman kapal asing dan eks asing dalam rangka pemberantasan illegal fishing oleh KKP ditentukan sejumlah variabel, yaitu kepastian dukungan peraturan perundangundangan, komitmen tinggi elit kebijakan Presiden dan Menteri, pola instruksional dan koordinasi yang efektif, dukungan anggaran tinggi, dan dukungan birokrasi satgas 115 yang berkinerja tinggi, sebagaimana terlihat pada gambar 5 dibawah ini.

Gambar 4. Variabel Implementasi Kebijakan Penenggelaman Kapal

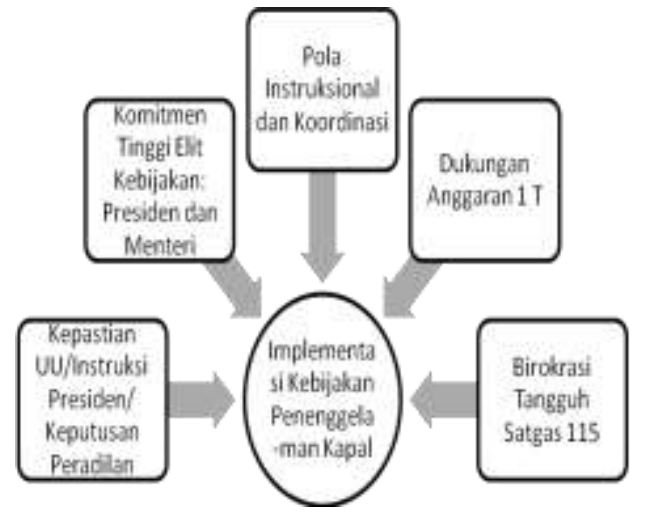

Sumber: Hasil Olah Data (2017)

Sejak dimulainya kebijakan penenggelaman kapal asing dan eks asing pelaku illegal fishing di era kepemimpinan Menteri KKP Susi Pudjiastuti tahun 2015 hingga 2016 telah memberikan dampak positif bagi perekonomian Indonesia, khususnya sektor kelautan dan perikanan. 
Sektor perikanan nasional menunjukkan hasil positif. Pada 2015, pertumbuhan Produk Domestik Bruto (PDB) sektor perikanan membaik dari 7,35 persen di tahun 2014, menjadi 8,37 persen. Produksi perikanan pun meningkat dari 20,40 juta ton menjadi 23,99 juta ton. Kenaikan nilai tukar nelayan (NTN) naik dari 102 sebelumnya ke 107 (http://kkp.go.id).

Fenomena implementasi kebijakan penenggelaman kapal oleh KKP dalam rangka pemberantasan illegal fishing merupakan fenomena implementasi kebijakan model top down. Kata kunci dari model implementasi kebijakan model top down adalah komando, perubahan, kontrol dan kepatuhan. Ini yang tejadi pada implementasi kebijakan penenggelaman kapal, instruksi tegas dan langsung dari Presiden dan kemudian diteruskan oleh Menteri KKP dengan memerintahkan Satgas 115 mengambil tindakan tegas. Instruksi diikuti dengan pengendalian ketat agar operasionalisasi tidak menyimpang dari intruksi. Selanjutnya, para birokrasi dibawahnya patuh terhadap instruksi untuk melaksanakan eksekusi penenggelaman kapal.

Model implementasi kebijakan penenggelaman kapal oleh KKP sejalan dengan pandangan Ripley dan Franklin (1986) yang mengemukakan tesis bahwa keberhasilan implementasi kebijakan ditentukan oleh tiga aspek: tingkat kepatuhan birokrasi terhadap birokrasi, kegiatan rutinitas yang lancar, dan keselarasan antara pelaksanaan kebijakan dan dampak yang diinginkan. Ketiga hal tersebut menggambarkan Implementasi kebijakan publik model top down yang ditentukan oleh faktor kekuatan dan paksaan dari pusat dengan mandat jelas dari peraturan perundang-undangan.

\section{B. Reaksi Lingkungan Kebijaka atas Implementasi Kebijakan Penenggelaman Kapal dalam Rangka Pemberantasan Illegal Fishing}

Implementasi kebijakan penenggelaman kapal yang telah dilakukan sejak tahun 2014, khususnya KKP dibawah Menteri Susi Pudjiastuti, mendapatkan dukungan sekaligus penolakan baik dari kalangan dalam negeri maupun luar negeri. Pada bagian ini akan dipaparkan sejumlah kontroversi dan penyebabnya dibalik implementasi kebijakan penenggelaman kapal asing dan eks-asing pelaku illegal fishing. Komplain terhadap kebijakan penenggelaman kapal asing dan eks-asing banyak dilakukan oleh negara-negara ASEAN dimana tempat asal dari pelaku illegal fishing sebagaimana gambar 5 dibawah ini.

Gambar 5. Jumlah Kapal yang ditenggelamkan dan asal negaranya

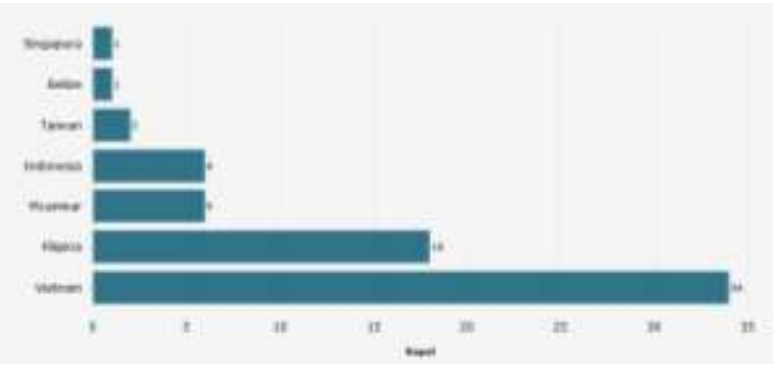

Sumber:http://databoks.katadata.co.id

Pertama, negara Vietnam melayangkan protes melalui Kedubesnya di Jakarta atas tindakan hukum Indonesia yang telah menenggelamkan kapal-kapal milik nelayan Vietnam. Sampai saat ini, sudah 50 buah kapal milik Nelayan Vietnam 
yang telah ditenggelamkan dan merupakan jumlah paling banyak ditenggelamkan (lihat gambar 5). (www.tribunews.com). Kedua, negara Thailand mengkritik kebijakan penenggelaman kapal yang dinilai keliru, kurang bersahabat, tidak ramah, dan tidak diplomatik. Tindakan hukum dengan kekerasan dinilai membahayakan kesatuan ASEAN yang tengah berproses menuju MEA. (http://jakartagreater.com). Sejauh ini sudah 43 kapal milik Thailand yang sudah ditenggelamkan dan menempati posisi kapal terbanyak kedua yang ditenggelamkan (lihat gambar 5). Ketiga, Pemerintah China menyorot langkah Indonesia yang menenggelamkan kapal penangkap ikannya. Negeri Tirai Bambu itu mengatakan keputusan pemerintah Indonesia menenggelamkan kapal telah menjadi perhatian serius negaranya. Kementerian Luar Negeri China pun mendesak pemerintah Indonesia memberikan penjelasan detail kenapa kapal yang disita 6 tahun lalu itu ditenggelamkan dengan cara diledakan (http://global.liputan6.com).

Protes kebijakan penenggelaman kapal dari pihak-pihak negara-negara tetangga Indonesia seperti Vietnam, Thailand, dan Cina di atas mempelihatkan bahwa setiap kebijakan yang dilaksanakan pasti akan mendapatkan reaksi lingkungan. Reaksi lingkungan luar negeri dalam konteks kebijakan penenggelaman kapal bersifat negatif, walaupun pada saat bersamaan reaksi positif juga datang dari internal dalam negeri berupa dukungan atas kebijakan tersebut.

Reaksi lingkungan yang negatif ditandai oleh protes dari negara-negara tempat asal kapal-kapal asing yang ditenggelamkan. Hal ini tentu dapat dipahami karena keberadaan Indonesia di kawasan Asia Tenggara sebagai suatu komunitas bersama yang tergabung dalam ASEAN. Komunitas ASEAN tentu telah menjadi suatu sistem pergaulan antar negara dalam berbagai aspek seperti tata pergaulan ekonomi, politik, hukum, budaya dan sebagainya. Apabila muncul perilaku kebijakan yang langsung maupun tidak langsung terkait dengan negara-negara ASEAN, maka akan menimbulkan reaksi. Inilah yang terjadi dalam konteks penenggelaman kapal-kapal asing dan eks asing pelaku illegal loging di perairan Indonesia.

Berbagai reaksi negara-negara ASEAN dalam bentuk protes dilayangkan ke Indonesia atas kebijakan penenggelaman kapal asing dan eks-asing. Negara Thailand protes terhadap Indoneisa karena kurang memperhatikan hubungan baik dengan negara Thailand ketika memutuskan menenggelamkan kapal. Negara Thailand juga mengancaman akan melakukan hal serupa terhadap nelayannelayan Indonesia yang masuk perairan Thailand. Negara Vietnam bereaksi dengan menyampaikan protes keras atas tindakan penenggelaman kapal-kapal milik nelayan Vietnam. Demikian juga dengan negaranegara ASEAN lainnya seperti Malaysia, Filipina, dan sebagainya. Ini yang dalam konteks implementasi kebijakan disebut sebagai aspek lingkungan dalam pelaksanaan suatu kebijakan.

Lingkungan kebijakan menjadi salah satu indikator keberhasilan pelaksanaan kebijakan publik. Apabila lingkungan mendukung penuh pelaksanaan kebijakan, maka implementasi kebijakan dapat 
dinyatakan berhasil. Sebaliknya, apabila variabel lingkungan menolak atau tidak mendukung, maka implementasi kebijakan belum berhasil dilaksanakan.

Dalam konteks implementasi kebijakan penenggelaman kapan pelaku illega fishing, variabel lingkungan belum solid mendukung kebijakan tersebut, sehingga implementasinya menimbulkan berbagai reaksi kontroversi baik dari dalam negeri maupun luar negeri. Situasi ini tentu dapat menjadi ancaman bagi keberhasilan pelaksanaan kebijakan pemberantasan illegal loging melalui tindakan penenggelaman kapal asing dan eks asing.

\section{Kesimpulan}

Implementasi kebijakan penenggelaman kapal asing dan eks asing yang dilakukan oleh KKP dalam rangka memberantas illegal fishing merupakan model top down. Model tersebut ditandai oleh beberapa variabel, yaitu kepastian dukungan peraturan perundang-undangan, komitmen tinggi elit kebijakan Presiden dan Menteri, pola instruksional dan koordinasi yang efektif, dukungan anggaran tinggi, dan dukungan birokrasi satgas 115 yang berkinerja tinggi. Implementasi kebijakan penenggelaman kapal asing pelaku illegal fishing dengan pola top down sangat kuat karena didalam pelaksanaannya terlihat jelas bagaimana kuatnya instruksi atau komando, eksekusi, perubahan nyata, dan kontrol ketat. Pelaksanaan kebijakan penenggelaman kapal asing pelaku illegal fishing mendapatkan reaksi yang kuat dari lingkungan kebijakan, khususnya lingkungan sistem politik kawasan ASEAN dan negara tetangga. Negara- negara tentangga Indonesia protes keras dan akan melakukan aksi balasan terhadap kebijakan penenggelaman kapal yang berasal dari negara mereka. Reaksi lingkungan ini tentu harus segera dikelola dengan baik Indonesia melalui KKP dan kementerian terkait lainnya agar tidak menjadi kendala besar dalam pelaksanaan kebijakan pemberantasan illegal fishing.

\section{Daftar Pustaka}

AG. Subarsono. 2006. Analisis Kebijakan Publik: Konsep Teori dan Aplikasi. Yogyakarta:Pustaka Pelajar.

Anderson, James A. 1976. Public Policy Making: Basic Concept in Political Sciences. New York: Praeger University Series.

Anderson, J. E. 2003. Public policymaking: An introduction. Boston: Houghton.

Grindle, Merilee S., (ed). 1980. Politics and Apolicy Implementation in the Third World, new jersey: Princetown University Press.

Kementerian PPN/Bappenas, Australian Aid, Pusat Pembinaan Analis Kebijakan dan LAN. 2015. Modul Pelatihan Analisis Kebijakan, Jakarta.

Mahmudah, Nunung. 2015. "Illegal Fishing”. Pertanggungjawaban Pidana Korporasi di Wilayah Perairan Indonesia. Jakarta: Sinar Grafika.

Mazmanian, Daniel H., dan Paul A. Sabatier. 1983. Implementation and Public Policy, New York: HarperCollins. 
Nazir, Moh. 2009. Metode Penelitian. Jakarta: Ghalia Indonesia

Quade, E.S. 1984. Analysis For Public Decisions, Elsevier Science Publishers, New York.

Ripley, Rendal B. and Grace A. Franklin. 1986. Policy Implementation and Bureaucracy, second edition, the Dorsey Press, Chicago-Illionis.

Wibawa Samodra, dkk. 1994. Evaluasi Kebijakan Publik, Jakarta:PT. Raja Grafindo Persada.

William N. Dunn. 2004. Public Policy Analysis: An Introduction. 3rd. Ed. Upper Saddle River, NJ: Pearson Prentice-Hall.

Majalah Mina Bahari. Edisi 1. April - Juni 2015. Illegal Fishing, No More. Komitmen Seirus Pemerintah Perangi Illegal Fishing.

http://www.bbc.com/indonesia/forum/2014 /11/141127_forum_kapal_asing, 28 November 2014.

http://statistik.kkp.go.id/sidatikdev/index.php?m=5, Kelautan dan Perikanan Dalam Angka Tahun 2009-2014, diakses 5 Maret 2017.

http://www.dikti.go.id/ikan-melimpah-dilaut kemana-nelayan-kita, di akses 5 Maret 2017.

http://id.beritasatu.com/agribusiness/kerugi an-akibat-illegal-fishing-capai-rp100triliun-per-tahun/8254, Kamis, 17 April 2014, diakses 5 Maret 2017.

http://id.beritasatu.com/agribusiness/tni-aldiajak-dukung-penenggelamankapal-asing-pencuri-ikan-di- indonesia/101519, Selasa, 2 Desember 2014.

http://djpsdkp.kkp.go.id/arsip/c/271/penga wasan-mendukung-kedaulatanpengelolaan-sumber-daya-kelautandan-perikanan/?category_id=22, diakses 24 Maret 2017.

http://pssat.ugm.ac.id/2016/03/24/mempert anyakan-tindakan-penenggelamankapal-asing/24 Maret 2016.

https://nasional.sindonews.com, Frans $\mathrm{H}$. Winarta , "Konsekuensi Penenggelaman Kapal", Kamis, 11 Desember 2014.

http://wartaekonomi.co.id, "Penenggelaman Kapal Asing, DPR: Anggarannya Tidak Jelas”, Senin, 16 Maret 2016.

http://kkp.go.id/category/kedaulatan, $\quad 20$ Maret 2017.

https://m.tempo.co/read/news/2016/02/22/s ejak-2014-151-kapal-ilegal-telahditenggelamkan, diakses 20 Maret 2017.

http://bisnis.liputan6.com/read/2235866/at uran-keluar-menteri-susi-ledakan-40kapal, diakses 18 Maret 2017.

http://bisnis.liputan6.com/read/2149108/ik uti-instruksi-presiden-susi-bakaltenggelamkan-7000-kapal, Selasa, 6/10/2015.

http://bisnis.liputan6.com/read/2235866/at uran-keluar-menteri-susi-ledakan-40kapal, 20 Mei 2015.

http://bisnis.liputan6.com/read/2386593/m enteri-susi-semua-kapal-pencuriikan-ditenggelamkan-tahun-ini, Kamis, 10 Desember 2015. 
https://finance.detik.com/ekonomibisnis/3049962/jadi-komandansatgas-menteri-susi-dapat-anggaranrp-1-t, Rabu, 21 Oktober 2015, pukul 18.06.

http://kkp.go.id/wpcontent/uploads/2016/04/1.SEKJEN.pdf.

https://kumparan.com/wijinurhayat/menteri-susi-siapkan-danahampir-rp-1-t-cegah-illegal-fishingdi-2017, Sabtu, 7 Januari 2017.

http://news.kkp.go.id/index.php/torehankinerja-satgas-115-kawalkedaulatan-laut-indonesia/, Rabu, 30 Juni 2016.

http://kkp.go.id/2016/04/02/menteri-susipastikan-sektor-perikanan-membaik/ http://databoks.katadata.co.id/datapublish/2 016/12/09/4-bulan-menteri-susitangkap-122-kapal-illegal-fishing http://jakartagreater.com/thailand-kritikkebijakan-penenggelaman-kapaljokowi, 7 Januari 2015.

http://global.liputan6.com/read/2237336/ka pal-nelayannya-ditenggelamkanchina-minta-penjelasan-indonesia, 22 Mei 2015

www.bakosurtanal.go.id/beritasurta/show/pentingnyan informasi geospasia untuk menata laut Indonesia, diakses 5 Maret 2017.

www.tribunews.com/nasional/2014/12/18/ vietnam-protes-penenggelamankapal-tiongkok-minta-penjelasan 